Case Report

\title{
Fat graft augmentation rhinoplasty compared to costal cartilage graft in saddle nose panfacial fractures
}

\author{
Dini Widiarni Widodo, Satria Dipo Putra Asmoro, Raden Ayu Anatriera \\ Department of Otorhinolaryngology Head and Neck Surgery, Faculty of Medicine, \\ Universitas Indonesia Dr. Cipto Mangunkusumo Hospital, Jakarta
}

\begin{abstract}
Background: Panfacial fracture can cause nasal function and esthetics alterations, one of which is saddle nose deformity. Post-traumatic saddle nose could be treated with augmentation rhinoplasty to correct the nasal structure and function. It can use autologous material such as fat graft and cartilage graft. Purpose: To report the effect of fat graft augmentation rhinoplasty compared to costal cartilage graft on patients' satisfaction of saddle nose panfacial fracture cases. Case report: Reporting two cases of panfacial fracture with saddle nose. The first case, a 22 -years-old female with multiple facial fractures underwent plate and screw fixation and nasal fracture close reduction followed by augmentation rhinoplasty using fat graft. The second case was a 23-years-old male diagnosed as blow-out fracture treated with internal fixation and costal cartilage augmentation rhinoplasty. Clinical question: Does fat graft augmentation rhinoplasty result in a better satisfaction level than costal cartilage graft in panfacial fracture with saddle nose cases. Review method: Evidence-based literature searching was performed through Pubmed, Scopus and Proquest databases to evaluate the effect of rhinoplasty augmentation using fat graft compared to costal cartilage on patient satisfaction level. Result: One study showed patient's high satisfaction level after fat graft augmentation procedure. Another study showed that satisfaction rates were also high in cartilage graft augmentation patients. Conclusion: The advantages of using fat graft augmentation are the more natural esthetic outcome, easy to perform and low morbidity. Rhinoplasty Outcome Evaluation (ROE) questionnaire could be used to evaluate the outcome of augmentation rhinoplasty with high sensitivity and specificity.
\end{abstract}

Keywords: saddle nose, panfacial fracture, fat graft augmentation, costal cartilage graft, ROE

\section{ABSTRAK}

Latar belakang: Fraktur panfasial dapat mengakibatkan perubahan struktur wajah disertai kelainan fungsi dan estetika hidung, salah satunya deformitas saddle nose. Saddle nose pasca trauma wajah dapat ditatalaksana dengan rinoplasti augmentasi untuk memperbaiki struktur dan fungsi hidung. Rinoplasti augmentasi dapat menggunakan material tandur autologous misalnya tandur lemak dan kartilago. Tujuan: Melaporkan hasil augmentasi tandur lemak dibandingkan tandur kartilago iga terhadap tingkat kepuasan pasien kasus saddle nose fraktur panfasial. Laporan kasus: Dua kasus fraktur panfasial disertai saddle nose. Kasus pertama, perempuan 22 tahun dengan fraktur wajah multipel, dilakukan fiksasi internal menggunakan plate and screw dan reduksi tertutup fraktur nasal, dilanjutkan rinoplasti augmentasi tandur lemak untuk memperbaiki saddle nose. Kasus kedua, laki-laki 23 tahun dengan fraktur blow-out ditatalaksana dengan fiksasi internal dilanjutkan rinoplasti augmentasi tandur kartilago iga. Pertanyaan klinis: Apakah rinoplasti augmentasi tandur lemak menghasilkan tingkat kepuasaan pasien lebih baik dibandingkan tandur kartilago iga pada kasus saddle nose pada fraktur panfasial? Telaah literatur: Pencarian literatur mengenai pengaruh augmentasi tandur lemak dibanding tandur kartilago iga terhadap tingkat kepuasan pasien fraktur panfasial dalam database Pubmed, Scopus dan Proquest. Hasil: Satu artikel menunjukkan tingkat kepuasan pasien pasca rinoplasti augmentasi tandur lemak yang tinggi dengan tingkat morbiditas rendah. Artikel lain menunjukkan tingkat kepuasan yang juga tinggi pada pasien augmentasi tandur kartilago tanpa komplikasi mayor. Kesimpulan: Keuntungan penggunaan tandur lemak pada rinoplasti adalah terlihat lebih alami, lebih 
mudah dilakukan dengan morbiditas rendah, akan tetapi dengan tingkat resorpsi tinggi. Kuesioner Rhinoplasty Outcome Evaluation (ROE) dapat menjadi alat untuk menilai outcome dari rinoplasti augmentasi dengan sensitivitas dan spesifitas cukup tinggi.

Kata kunci: saddle nose, fraktur panfasial, augmentasi tandur lemak, tandur kartilago iga, ROE

Correspondence address: Dini Widiarni Widodo, Plastic Reconstruction Consultant, Department of Otorhinolaryngology Head and Neck Surgery, Faculty of Medicine, Universitas Indonesia-Cipto Mangunkusumo Hospital. J1. Diponegoro No. 71, Jakarta 10430, Indonesia. Email: dini_pancho@yahoo.com.

\section{INTRODUCTION}

Facial trauma could implicate the face's soft tissue and bony components, such as the mandible, maxilla, zygoma, naso-orbitalethmoid complex, supraorbital structures, and gingiva. Approximately $40 \%$ of facial fractures occur in the nasal region. Nasal and nasal-septal complex fractures are the most common facial fractures because the nose is a protruding structure and located in the central part of the face. The thin structure of the nasal bones also makes them prone to injury. The cause of nasal fractures is usually due to sport traumas, falls and accidents. ${ }^{1,2}$ Nasal fracture could result in soft tissue damage such as lacerations, ecchymosis, and hematomas outside or inside the nose. Any force from lateral side could result in an ipsilateral depressed fracture or an open fracture of the opposite nasal bone, causing deviation of the entire nose. The pressure exerted through the nasal bone and upper lateral cartilage could also dislocate the maxillary crest of the septum, causing structural instability on the superior side and causing obstruction of the airway. ${ }^{3,4}$

Nasal-septal fractures in facial trauma could also cause saddle nose. This deformity is characterized by nasal dorsum depression, loss of tip support, columellar retrusion, vertical length shortening, excessive nasal tip rotation, and nasal bones and septum retrusion. ${ }^{5}$ Tardy classified the saddle nose into three categories: (1) minimal, characterized by nasal depression above the supratip due to loss of septal support resulting in mild retraction of the columellar base, while tip projection and rotation are not affected, (2) moderate, loss of nasal dorsum height of $<5$ $\mathrm{mm}$. The moderate deformity could cause low tip projection and tip cephalic rotation, (3) severe, characterized by loss of cartilage, low tip projection and wider nostrils. ${ }^{6}$

In some facial trauma cases, after the fixation and closed reduction procedures, there could be a persistent nose misalignment and saddle nose that requires rhinoplasty augmentation. The procedure is preceded by an initial analysis through assessing not only the nose, but also the facial features and the morphological characteristics of the patient's face and body. After the open reduction internal fixation (ORIF) had been performed, the nose then, re-evaluated to plan the technique for reconstructive rhinoplasty according to patient's pre-trauma morphology. The material chosen for posttraumatic rhinoplasty is autologous grafts. Autologous grafts are more available, ideal, more natural, and resulting in minimal immunological reactions. ${ }^{7,8}$

Cartilage is the most commonly used graft because it could be used as a structural graft and fill the organ recipient's space, and it is easy to adjust to the recipient's shape and size. The graft could be harvested from the $5^{\text {th }}$ to $9^{\text {th }}$ costal ribs, but the $7^{\text {th }}$ rib is preferred. The cartilage should be separated 
from the perichondrium, gently carved from all sides until the cartilage is exposed and easy to remove. After the costal cartilage harvesting, the serious risk is post-removal pneumothorax, but it could be minimized with proper extraction technique. The donor site morbidity included pain and incision scar. ${ }^{8}$

Fat grafts are known to be the right choice for soft tissue augmentation material in plastic surgery. In early 1893 , free fat had been used by Neuber to fill soft tissue defects. The use of autologous fat from the abdomen to correct malar and cheek defects was first reported in 1909. The development of fat transplantation techniques coincided with the popularity of liposuction in the 1980s. Illouz, in 1984, reported fat transfer from liposuction. In 1986, Ellenbogen reported the use of free fat in facial atrophy and post-traumatic facial defects. Fat transplantation has become the chosen procedure to treat facial problems, including facial scarring, lip augmentation, and facial rhytides (especially in difficult areas such as the nasolabial and glabellar folds). ${ }^{3,9}$

The disadvantage of rhinoplasty using fat graft is high resorption rate. One of the indications of fat graft rhinoplasty is saddle nose case.${ }^{10}$ Tan et al. ${ }^{11}$ stated that combining costal cartilage with fat grafting provided outcomes that did not cause silhouette abnormalities.

Evaluation of the post-surgery patient's satisfaction could be assessed by Rhinoplasty Outcome Evaluation (ROE). Alsarraf in the year 2000 created and used ROE as a questionnaire with high reliability, internal consistency, and validity in several esthetic surgery cases, including rhinoplasty. This questionnaire is a qualitative measurement that includes the patient's social, emotional, and psychological aspects. ROE scoring is categorized into: 0-6 not good, 7-11 good, and $>12$ very good. ${ }^{12}$

This case report was published to broaden and expand the knowledge concerning the role of fat and costal cartilage graft in augmentation rhinoplasty on panfacial fracture patients with saddle nose.

\section{CASE REPORT 1}

A 22-years-old female patient with a history of a motorcycle accident one week prior to hospital admission. She fell from a motorcycle at high speed and hit street pavement flat on her face. The patient wore a helmet, but it broke during the accident. There were complaints of nosebleeds after the accident, accompanied by nasal congestion. The patient had subarachnoid hemorrhage, and accordingly, craniotomy and debridement were performed at local hospital.

Physical examination showed that the nasal cavity was narrow with serous secretions. The inferior turbinates were eutrophic, and deviated septum and cristae could be seen from anterior to posterior on both sides of nasal septum. The nasal region showed dry wound sutures, lacerations, and crepitus. According to Tardy's classification, it was classified as moderate- severe saddle nose deformity. The right orbital region showed a dry wound suture. The frontal region showed a suture scar. The zygomatic region had edema, deformity, and crepitus. The maxillary region had edema, deformity, crepitus, and floating maxilla. On the mandibular region, there was 3 fingers trismus, malocclusion, and crepitus.

Three-dimension facial CT scan revealed a panfacial fracture, including an impressive fracture of the frontal bone, nasomaxillary orbital rim, bilateral maxilla, nasal bone, mandibular bone, and dentoalveolar bone (Figure 1).

The diagnosis was multiple facial fractures. She was intubated through the nose, followed by installing an arch bar to attain maxillary and mandibular occlusion. The sublabial incision was performed, followed by 
separating the soft tissue until the fracture was exposed as high as Le Fort I. Then, the fracture area was repositioned until the $1^{\text {st }}$ molars and canines were in the normal line. The occlusion was maintained with installation of arch bars and ivy loops. The L-shaped titanium plate number 1.6 was attached to the maxilla and orbital rim with number 0.4 screws. Through the open wound in the frontal region, plates were placed on the medial frontonasal, frontal processes of the nasal bones and the nasomaxillary region, as to secure the fixation. Afterwards, the intubation tube was shifted to the mouth. Nasal deformities were corrected by repositioning the nose laterally, medially, and anteriorly using Asch and Walsham forceps. The repositioning results showed that the alignment was quite good, but the saddle nose still existed. The procedure was followed by augmentation using abdominal fat graft taken from below umbilical region. First, the fat graft was cleansed, cut into small pieces, and put into a syringe. After determining the boundary on the nasal dorsum as recipient site, the graft was inserted. The fixation was implemented with Steri Strip and plaster. The scar was sutured in the frontal, nasal and superior labial areas using Prolene 5.0 sutures.

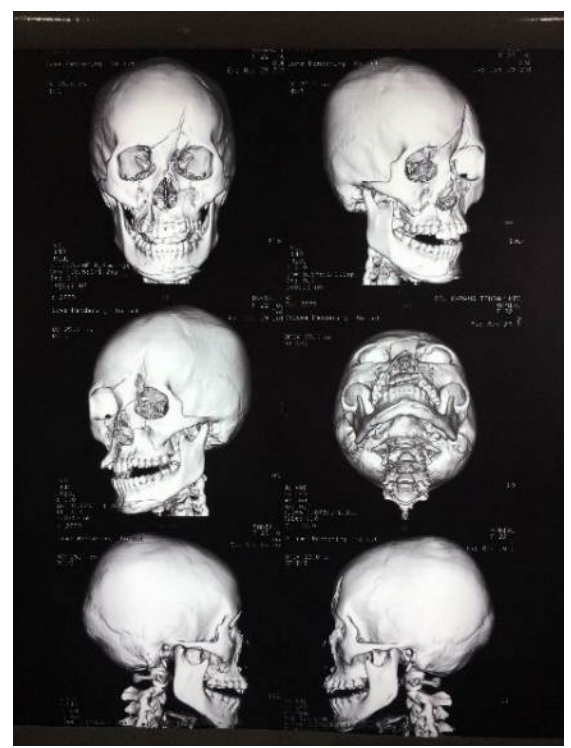

Figure 1. Facial 3D CT-Scan
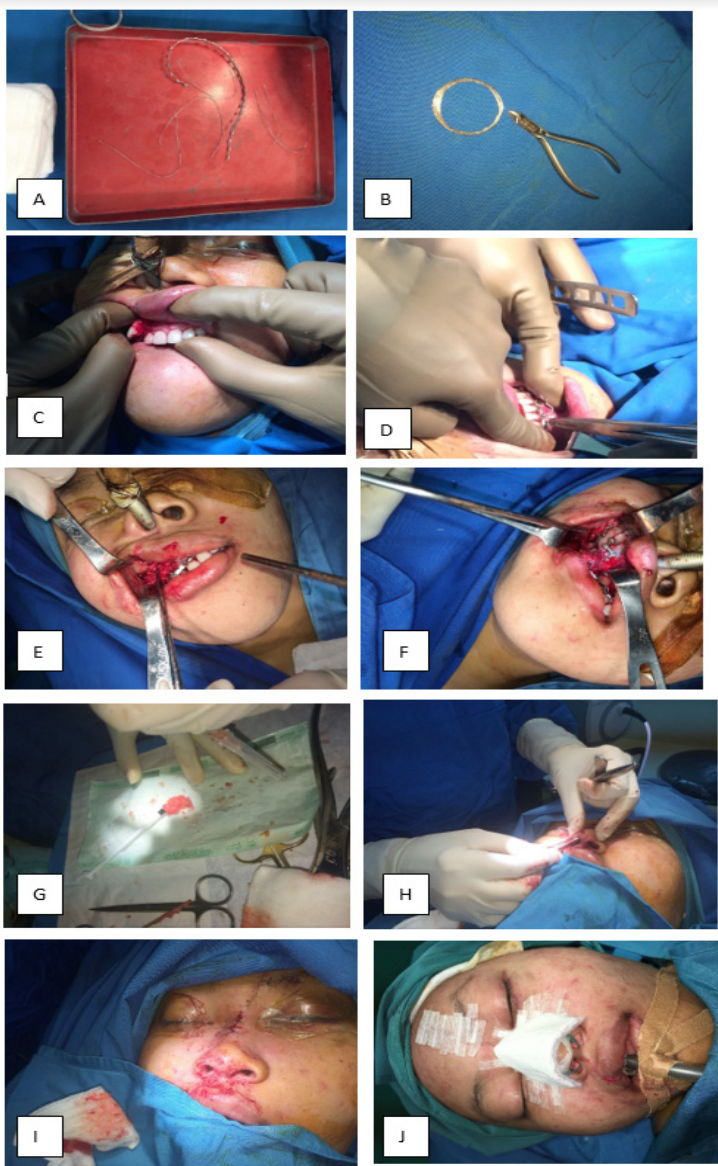

Figure 2. Patient number 1

Figure 2A. 2B Archbar and wire

Figure 2C. 2D Installation of archbar and wire Figure 2E. 2F Fixation of the maxilla with Lshaped plate and screw

Figure G. Fat graft

Figure H. Fat graft implantation with endonasal rhinoplasty approach

Figure I. Wound suture

Figure J. Fixation with Steri strip and plaster

There were no complaints of nasal congestion, nosebleeds, headache, nor facial pain in the first- and second week post-surgery evaluation. On post-operative physical examination of the nasal region, there were no edema, hyperemia, hematoma, nor crepitus. Assessment of post-operative satisfaction was carried out one month post-surgery using ROE questionnaire with results of $2 / 2 / 2 / 2 / 3 / 0$, and the symptoms evaluation of nasal obstruction using the Nasal Obstruction and Septoplasty Effectiveness (NOSE) questionnaire with results of $0 / 0 / 0 / 0 / 0$. 

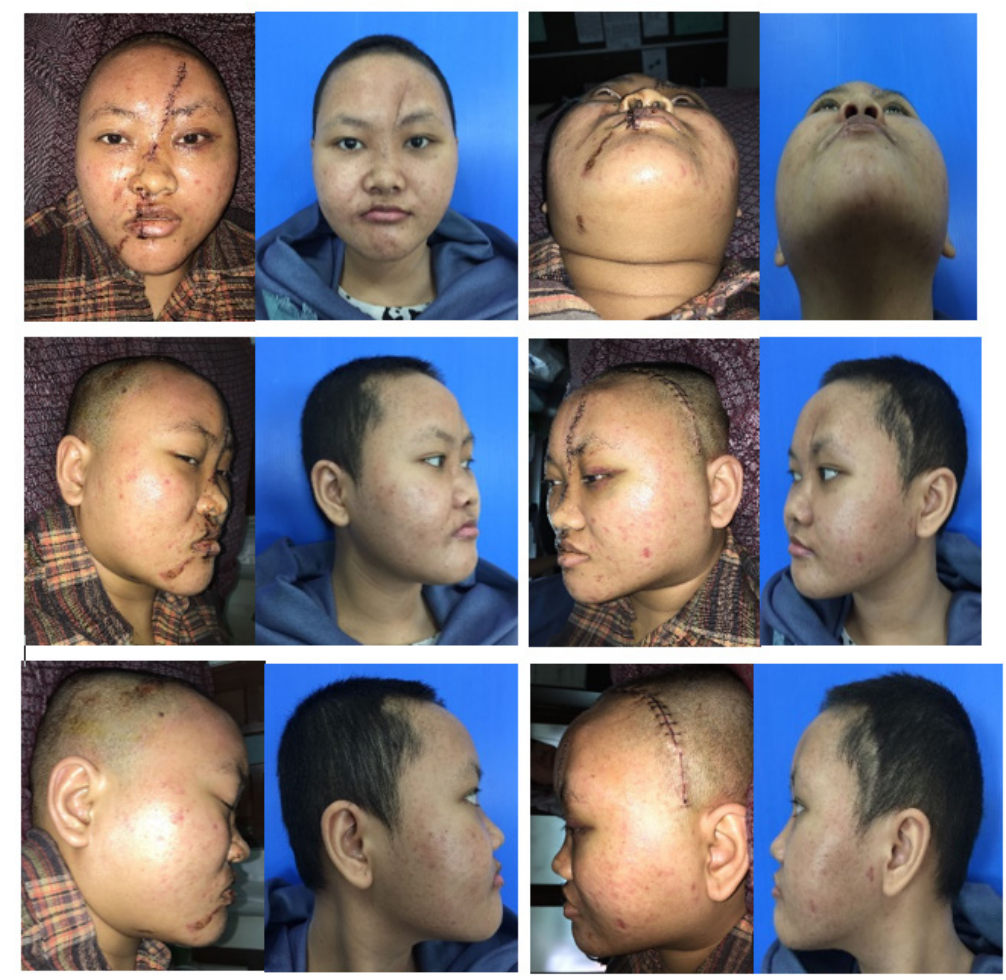

Figure 3. Patient no.1. Pre-operative and 1-month postoperative
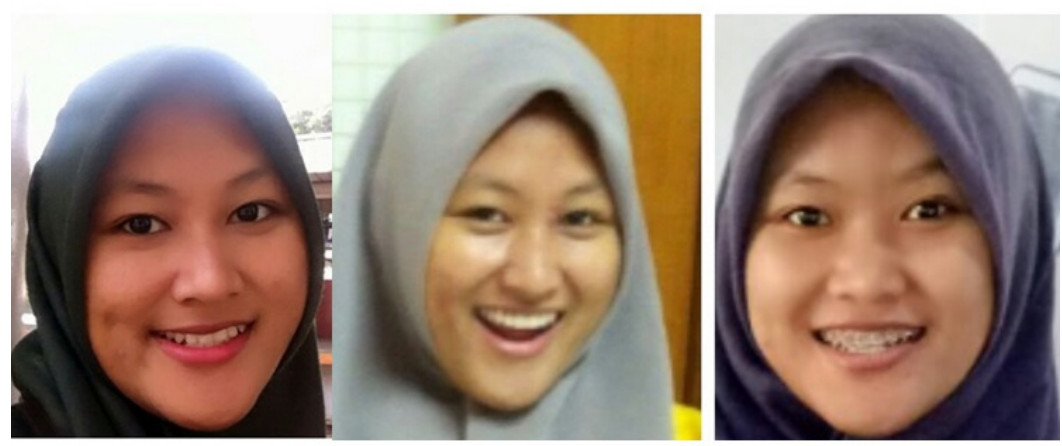

Figure 4. Patient no.1. One year postoperative

\section{CASE REPORT 2}

A 23-years-old male patient was referred from Jakarta Hospital with complaints of sandy sensation of the right eye, facial asymmetry and malocclusion after a motorcycle accident two months prior to hospital admission. The nasal congestion symptom persisted, accompanied by gritty sensation in the eye. There were no visual symptoms.

Nose examination showed no abnormalities. The orbital region appeared deformed with intercantal distance of $>1.5$ $\mathrm{cm} />1.5 \mathrm{~cm}$. Seen malar depression in the zygoma region, and deformity in the maxillary region. There was malocclusion, asymmetric right and left zygoma, and severe saddle nose.

The CT scan showed complete fractures of the right frontozygomatic bone, right zygomatic bone, right zygomaticomaxillary bone, intermaxillary, bilateral sphenoid wing and inferior wall of bilateral frontal sinus. Besides, a complete comminuted fracture of the left zygomatic bone was seen. There were multiple complete fractures of bilateral anterior and superior maxillary walls (inferior 
orbital rim), right lateral and posterior maxillary walls causing inferior herniation of some fat, along with left and right inferior rectus muscle, complying with diagnosis of blow-out fracture (Figure 5).

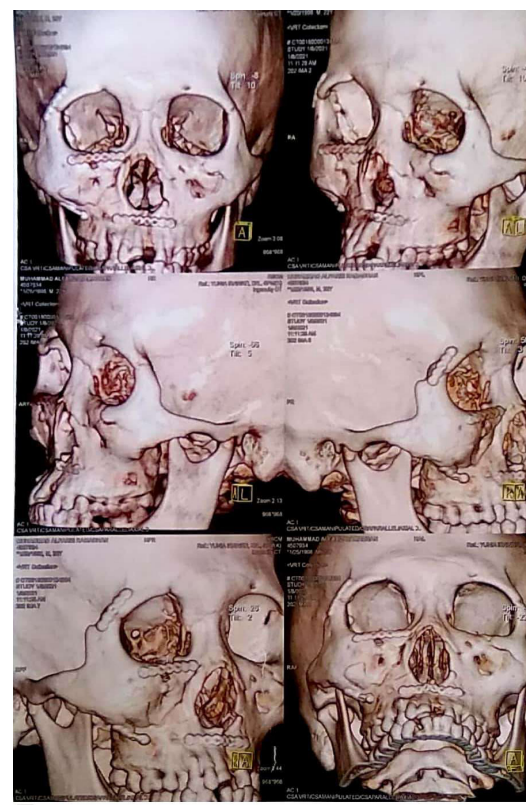

Figure 5. The 3-D facial CT-Scan

The corrective surgery of the orbital floor and orbital rim was performed cooperatively with the Ophthalmology Department. Bilateral subciliary incisions were made to reconstruct the rim and orbital floor. Right eye canthotomy was performed and the periorbital soft tissue which was trapped in the fracture was detached, so the orbital floor fracture of the right eye could be identified.

In the orbital floor fracture of the right eye, there was inferomedial fracture to the medial wall, a plate-screw was attached to the anterolateral orbital rim of the inferior. The procedure was also performed in the left eye. In the orbital floor fracture of the left eye, there was an inferolateral fracture and entrapment of the rectus orbicularis oculi muscle was seen which was finally released. A silicon block was placed on the right and left orbital floor. Then the ORIF of panfacial fracture was followed by external rhinoplasty using a costal cartilage graft. The incision was made $\mathrm{V}$-inverted. The dorsum of the nose was corrected using a radix graft, a spreader graft, a septal extension graft and a dorsal graft.

On one month post-operative evaluation, there were no nasal congestion symptoms (NOSE score of $0 / 0 / 0 / 0 / 0$ ) and ROE score of $2 / 1 / 0 / 2 / 2 / 1$. On physical examination, edema was seen in the right orbital region. No edema at the left nasal and infraorbital regions.
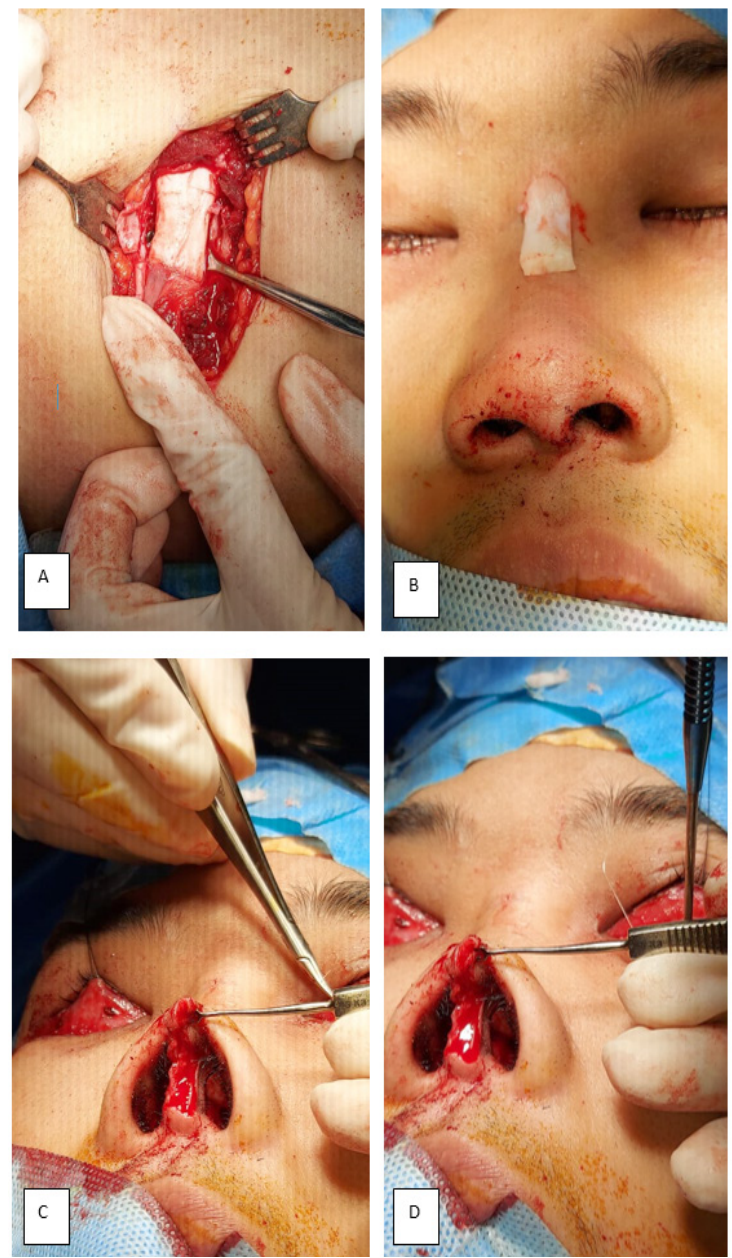

Figure 6. Durante operation of a cartilage graft augmentation rhinoplasty.

Fig. 6A. The 6th costal cartilage was harvested. Fig. 6B. The cartilage is divided for radix graft. Fig. 6C. A transcolumellar incision was made. Fig. 6D. The nasal dorsum was corrected with a radix graft, a spreader graft, a septal extension graft and a dorsal graft. 

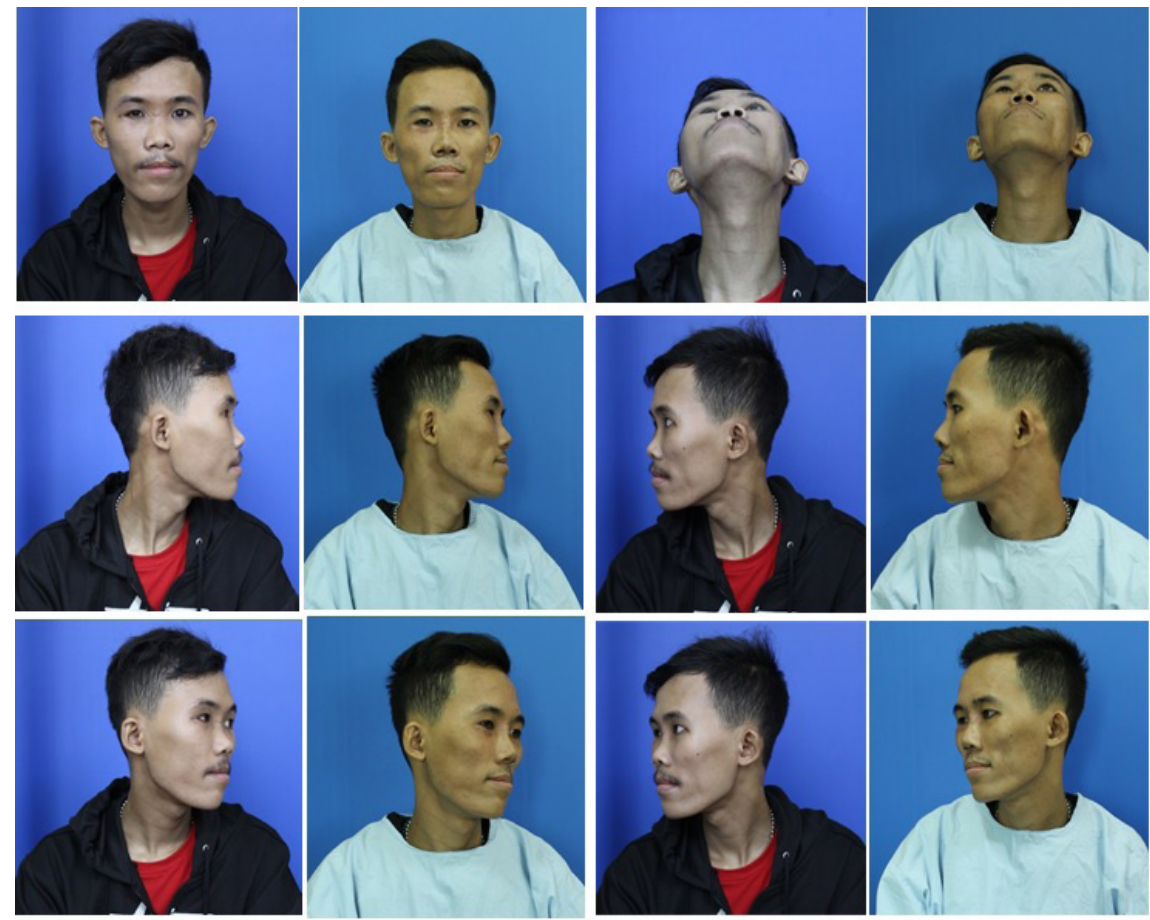

Figure 7. Preoperative and 1-month pos-toperative

\section{CLINICAL QUESTION}

P : Patients with saddle nose in a panfacial fracture.

I : Fat graft augmentation rhinoplasty.

$\mathrm{C}$ : Costal cartilage graft augmentation rhinoplasty.

$\mathrm{O}:$ A better patient satisfaction.

Does fat graft augmentation rhinoplasty result in better patient satisfaction than costal cartilage graft in the case of saddle nose in panfacial fracture?

\section{REVIEW METHOD}

The clinical questions could be answered using evidence-based medicine method. A literature search was carried out in the past ten years through 3 databases (Pubmed, Scopus and Proquest). The main keyword used in this literature search was "saddle nose", AND "fat graft" AND "costal cartilage graft" AND "satisfaction level". These articles were selected based on inclusion criteria: (1) studies related to fat graft augmentation or costal cartilage grafting; and (2) saddle nose with panfacial fracture, while the exclusion criteria: (1) saddle nose with non-traumatic etiology; and (2) non-English speaking studies.

\section{RESULTS}

Searching articles in the three databases resulted in a total of ten articles. The author did a selection based on the title and abstract, as well as inclusion criteria, exclusion criteria and full-text availability.

Monreal ${ }^{13}$ conducted a retrospective case study of 36 surgeries performed on 33 patients with a maximum follow-up of 14 months. In 18 patients, fat graft augmentation was performed to improve nasal esthetics; these patients refused the standard rhinoplasty procedure. Meanwhile, in 15 patients, nasal fat augmentation was performed as a complementary procedure to either open or closed rhinoplasty. In general, patients who had clinical features of short nasal bones, 
frontal recession or premaxillary retrusion had been treated with cartilage grafts during rhinoplasty to correct the bone deficiency in these areas. However, Monreal study assessed the effectiveness of fat grafting as an alternative to repair nasal deformities. Follow-up was performed at 7 days, 15 days, 3 months, 6 months and 12 months postoperatively to assess changes in shape, assessed from esthetics and the level of patient satisfaction before and after surgery. Although it was not clear what type of questionnaire was used to assess patient satisfaction, it was found that $80 \%$ of patients had a high level of satisfaction after undergoing the fat graft augmentation procedure; only two patients were disappointed with the results.

The second article is a study by Park et al. ${ }^{14}$ on 43 post-traumatic patients who underwent augmentation rhinoplasty costal cartilage graft. The patient satisfaction level was assessed 1 to 2 years after surgery, with a classification of very good (80-100), good (60-80), moderate (40-60), poor (20-40), and very poor $(0-40)$. The evaluation results showed a very good level of satisfaction in 37 patients, moderate in 4 patients and poor results in 2 patients. No skin necrosis or graft dislocation was found.

\section{DISCUSSION}

The management for saddle nose case is surgery to restore the morphology and function of nasal dorsum to its original state. The appropriate surgery is augmentation rhinoplasty, which involves graft implantation, either from the patient's own body (autogenous), or non-organic compounds (alloplastic), to reconstruct the nasal shape. Nasal analysis is important to determine the severity of the saddle nose. Radix height is a fundamental variable to determine the nasal characteristics of each patient. Ideally, the vertical nasal position is between the supratarsal folds and at the upper eyelid line. ${ }^{6}$ Nose height could be analyzed by evaluating the distance between the nasion and the lowest point of the nose. The nasal dorsum length was assessed by measuring the distance between the nasal base and nasal tip. If there is a tip depression of the nasal dorsum, it is necessary to estimate the desired ideal projection. Besides the dorsum height, examination should be performed to ascertain the presence or absence of the nasal septum. This evaluation could be executed using palpation, anterior rhinoscopy, or imaging. The main goal of surgery is to restore the support function of the nose, and to correct the shape of the nose. Therefore, surgery on saddle nose cases is performed by improving the structure and esthetics of the external nose. ${ }^{15}$

Preoperative and post-operative analysis could be performed by photography. The facial profile was photographed taking the whole face, superior, and basal view. ${ }^{16}$ In both cases of the panfacial fracture in our case report, the assessment was carried out when the ORIF was completed.

The autologous grafts (originated from the body itself), include bone, cartilage and fat. ${ }^{1}$ Bone was initially the most common used graft to treat the saddle nose. Reconstruction using bone had been done since 1861, using the frontal bone. In addition, bone could be obtained from the iliac crest. However, the use of bone and cartilage in cases of panfacial fracture will prolong the operation time with a high level of difficulty and requires more accuracy. The use of bone on the nasal dorsum could undergo bone resorption. ${ }^{17}$ In this case report, the grafts used were fat graft in the first case and costal cartilage graft in the second case.

The first case was a multiple facial fractures in a 22 years-old female patient. The fixation with plate and screw was performed for the maxillary and zygoma fracture. There was a persistent saddle nose after the fracture fixation procedure, therefore 
fat graft augmentation rhinoplasty was warranted to improve the nose shape. The fat graft was taken from the umbilical area, cut into small pieces and cleaned out of blood. Arcuri et al. ${ }^{18}$ preferred that fat grafts taken from the abdominal and femoral area were centrifuged to produce fat with low blood cell levels. According to various studies as cited by $\mathrm{Pu}^{19}$ the purpose of centrifugation is to make adipocytes more viable to stimulate extracellular matrix synthesis and to facilitate colonization of grafts by endothelial cells, thereby stimulating preadipocytes, allowing for reconstruction of the grafted tissue.

According to Arcuri et al. ${ }^{18}$ Fat graft rhinoplasty is an excellent modality for repairing post-traumatic maxillofacial deformities. Rhinoplasty with fat grafts is a safe procedure with low morbidity. Erol ${ }^{20}$ stated that fat grafts could correct minor or moderate abnormalities of the nose. This procedure is less invasive than the use of a cartilage graft. Fat grafting does not cause post-operative complications. Tan et al. ${ }^{11}$ also stated that the advantage of using fat in rhinoplasty was no rejection reaction from the recipient site. There was no migration and it looked more natural from esthetic point of view. One of the complications that may occur in fat graft augmentation is the reduction in volume due to graft resorption.

The second case was a bilateral blow-out fracture that underwent orbital rim and orbital floor ORIF. Severe saddle nose that persisted after fracture fixation was repaired by costal cartilage graft augmentation rhinoplasty. Cartilage is an ideal graft material, especially for structural rhinoplasty. Cartilage has a mild reaction to surrounding tissue. The level of elasticity, rigidity, and flexibility of cartilage is also very suitable for the nose morphology. This material is easy to harvest, shape, and withstand the traction forces during the wound healing. Cartilage is less prone to resorption compared to bone. ${ }^{17}$
The study by Moon et al. ${ }^{21}$ reported that in 108 patients who underwent cartilage graft augmentation rhinoplasty, 73 patients were satisfied with the post-operative results, 16 patients stated that the operation results were better than the preoperative appearance, while 19 patients were not satisfied with the results. Although the level of patient satisfaction was quite high, Moon's study found post-operative complications in 13 patients in the form of seroma, pneumothorax and keloid in the thoracic area, and graft resorption, warping and infection in the recipient area. The high infection rate may be caused by the low blood supply to the recipient area, especially when a scar had been formed in revision rhinoplasty. The shape of the graft that was too thin could lower supporting capacity and causing higher infection risk.

The cartilage graft in our case report was taken from the $6^{\text {th }}$ rib. The cartilage could be harvested from the nasal septum, auricular conchae, or fat grafts in mild or moderate saddle noses. In more severe cases, the costal cartilage might be used. The costal cartilage is hyaline cartilage and has sufficient rigidity. The amount and sufficient thickness generally are from $6^{\text {th }}$ or $7^{\text {th }}$ ribs.

There are two types of rhinoplasty approaches in saddle nose surgery: open approach and endonasal approach. The open approach is a surgical method by making an incision in the columella between the nostrils. The endonasal approach is performed through an incision in the interior of the nose. The advantage of the endonasal approach is postoperative symptoms such as swelling and the incision wound would heal faster. However, in more severe cases of surgery, the use of open approach is preferable due to easier graft implantation in the saddle nose surgery. In addition, the open approach provides better visualization of the operation field. ${ }^{17}$ If the columellar closure was performed properly, the wound would be minimal. The wound in open approach patients would 99\% recover in 3-6 months. ${ }^{16}$ 
The surgical technique was carried out starting with an incision in the nasal columella, followed by opening the nasal septum in the paraseptal sac for graft implantation. Suturing was then, performed to fix the graft position to the nasal bone with non-absorbable steel suture. Subsequently, the septal splint was inserted and connected to the anterior nasal spine, followed by the columella re-insertion to obtain a projection of the tip of the nose. The surgery was finalized with closure of the fascia to restore the nasal dorsum. ${ }^{16}$

One of the instruments to evaluate the rhinoplasty result is through patient satisfaction in the form of a questionnaire that evaluates the quality of life and assessing nasal obstruction with Nasal Obstruction and Septoplasty Effectiveness Scale (NOSE). In this case report, the level of patient satisfaction was assessed using the ROE questionnaire. Fat graft augmentation rhinoplasty patients gave a good rating of rhinoplasty results with ROE score of 11 and cartilage graft augmentation patients rated well with $\mathrm{ROE}$ score of 8 . The ROE questionnaire is very easy to translate and to be used even in patients with low educational levels. Filling out the questionnaire could be done quickly and the possibility of missing data is lower than other questionnaires. The study by Izu et al. ${ }^{22}$ showed that the sensitivity of ROE was $95.16 \%$ with a specificity of $95 \%$.

In this case report, it could be concluded that fat graft augmentation rhinoplasty produced a high level of patient satisfaction with low morbidity. Yet, this procedure had a fairly high resorption rate of the graft. Meanwhile, using costal cartilage grafts as a structural graft resulted in the same level of satisfaction, with lower resorption rate but higher morbidity. Fat grafts could be used to fill in the empty areas of tissue in the deformity to provide better esthetics. Costal cartilage and fat grafts could be used depend on variations of patient's condition after a panfacial fracture.

\section{REFERENCE}

1. Chegar BE, Tatum SA. Nasal fracture. In: Flint PW, Haughey BH, Lund VJ, Niparko JK, Richardson MA, Robbins KT, et al., editors. Cummings Otolaryngology Head $\&$ Neck Surgery. 5th ed: Mosby; 2010. p. 496-507.

2. Hoffmann JF. An algoritm for the initial management of nasal trauma. University of Washington. Department of Otolaryngology. Facial Plasty Surgery; 2015. p. 183-193.

3. Widiarni DW. Atlas dan teknik diseksi septorinoplasti. In: Atlas Panduan Praktis Septorinoplasti dan Koreksi Wajah. 4th Ed: FKUI; 2016. P. 3-40

4. Thiagarajan B. Fracture nasal bones. Stanley Medical College; 2013. Vol 3. p. 2250-0359.

5. Daniel RK, Brenner KA. Saddle nose deformity: a new classification and treatment. Facial Plast Surg Clin N Am. 2006 Nov;14(4):301-12.

6. Beekhuis GJ. Saddle nose deformity: etiology, prevention, and treatment; augmentation rhinoplasty with polyamide. The Laryngoscope. 1974 Jan; 84(1): 2-42.

7. Brenner MJ, Xavier R. Rhinoplasty; Modified Delivery Approach-A New Perspective. Janeza Trdine 9, 51000 Rijeka, Croatia. 2011. 45-53

8. Nataraj RV, Mohan J, Reshma C, Kartik P, Reshma H, Arpita S, et al. Augmentation grafts in septorhinoplasty: our experience. Int J Otolaryngol Head Neck Surg. 2015; 4: 317-24

9. Rizaliyana S, Perdanakusuma D. An experience using fat graft and wire scalpel in reconstruction lower limb defect. Universitas Surabaya. 2013.

10. Zhu M, Cohen SR, Hicok KC, Shanahan RK, Strem BM, Yu JC, et al. Comparison of three different fat graft preparation methods: gravity separation, centrifugation and simultaneous washing with filtration in a closed system. Plast Reconstr Surg.2013; 131(4): 873-79

11. Tan O, Algan S, Cinal H, Barin EZ, Kara $\mathrm{M}$, Inaloz A. Management of saddle nose deformity using dermal fat and costal cartilage "sandwich" graft: a problemoriented approach and anthropometric 
evaluation. Oral Maxillofac Surg: Off J Am Assoc Oral Maxillofac Surg. 2016; 74:1848. e1-e14.

12. Esteves SS, Ferreira MG, Almeida JC, Abrunhosa J, Sousa CA. Evaluation of aesthetic and functional outcomes in rhinoplasty surgery: a prospective study. Braz J Otorhinolaryngol. 2017;83(5):552-57.

13. Monreal J. Fat grafting to the nose: personal experience with 36 patients. Aesthetic Plast Surge. 2011; 35: 916-22.

14. Park SH, Kang B, Chung JH, Eun S. Posttraumatic augmentation rhinoplasty using an osseocartilaginous cantilever graft. Ann Plast Surg. 2019: 1-4.

15. Suhk J, Park J, Nguyen AH. Nasal analysis and anatomy: anthropometric proportional assessment in asians. Aesthetic Balance from Forehead to Chin, Part I. Semin Plast Surg. 2015 Nov;29(4):219-25.

16. Tasman AJ. Rhinoplasty-indications and techniques. GMS Curr Top Otorhinolaryngol Head Neck Surg [Internet]. 2008 Mar 14 [cited 2019 Apr 13];6. Available from: https:/www.ncbi.nlm.nih.gov/p mc/articles/ PMC3199847.

17. Tito Matteo M. Saddle Nose: A Systematic Approach. In: Contemporary Rhinoplasty - What's New? [Working Title] [Internet]. IntechOpen; 2018 [cited 2019 Apr 9]. Available from: https://www.intechopen. com/online-first/saddle-nose-a-systematicapproach.

18. Arcuri F, Brucoli M, Baragiotta N, Stellin L, Giarda M, Benech A. The role of fat grafting in the the treatment of post-traumatic maxillofacial deformities. Craniomaxiilofacial Trauma Reconstruction. 2013;6: 121-26.

19. $\mathrm{Pu}$ Lee LQ. Towards more rationalized approach to autologous grafting. J Plast Reconstr Aesthet Surg. 2012; 65(4): 413-19.

20. Erol OO. Microfat grafting in nasal surgery. Aesthet Surg J. 2014; 34(5): 671-86.

21. Moon BJ, Lee HJ, Jang YJ. Outcomes following rhinoplasty using autologous costal cartilage. Arch Facial Plast Surgery. 2012; 14(3): 175-80.

22. Izu SC, Kosugi EM, Brandao KV, Lopes AS, Bagrcia LBS, Suguri VM, et al. Normal values for the rhinoplasty outcome (ROE) questionnaire. Braz J Otorhinolaryngol. 2018; 78(4): 76-9. 